\title{
Donor Regulatory T-lymphocytes
}

National Cancer Institute

\section{Source}

National Cancer Institute. Donor Regulatory T-Iymphocytes. NCI Thesaurus. Code C111894.

Donor-derived regulatory $\mathrm{T}$-cells (Tregs), with potential immunomodulating activity.

Tregs are a subset of CD4+ T cells that express high levels of CD25 (interleukin 2 receptor) and the transcription factor Foxp3. The donor CD4+CD25+ Tregs modulate immune responses and may induce tolerance to allogeneic organ transplants, such as hematopoietic stem cell transplants (HSCTs), thereby preventing graft-versus-host disease (GVHD). 